ks. Leszek Adamowicz

\title{
Przynależność kościelna i obrządkowa dziecka
}

„Przez chrzest osoba zostaje wcielona w Chrystusa i w Kościół, dokonuje się to konkretnie w Kościele lub w określonej Wspólnocie eklezjalnej". Powyższe stwierdzenie zapisane w nowym Dyrektorium ekumenicznym uzasadnia konieczność podjęcia tematu określonego w tytule.

\section{Przynależność do Kościoła owocem wychowania}

W czasie katolickiej celebracji, podczas której kobieta i mężczyzna zawierają sakramentalne małżeństwo, pada pytanie: „Czy chcecie przyjąć i po katolicku wychować potomstwo, którym Bóg was obdarzy?". Twierdząca odpowiedź obojga stanowi jeden z elementów koniecznych, by uznać skuteczność małżeńskiego konsensu. Małżonkowie zaciągają zobowiązanie nie tylko do zrodzenia, ale i do wychowania potomstwa. Prawodawca stwierdza wprost, że „ponieważ dali dzieciom życie, spoczywa na nich bardzo poważny

1 Pontificium Consilium ad Unitatem Christianorum Fovendam, Directorium oecumenicum noviter compositum, „Acta Apostolicae Sedis” [dalej: AAS] 85 (1993), s. 1039-1119, n. 97 [dalej: Dyrektorium]. 
obowiązek i prawo ich wychowania" (kan. $226 \S 2^{2}, 793 \S 1^{3}$ i 11364). Na wychowanie składają się różne jego aspekty: wychowanie fizyczne, społeczne, kulturalne, moralne i wreszcie wychowanie religijne. Jak stwierdza Elżbieta Szczot, „rodzina tworzy chrześcijańską wspólnotę wychowawczą, w której małoletni wierni wzrastają do pełni człowieczeństwa i do udziału w wierze i życiu Kościoła”s. Stąd też bardzo znaczącym obowiązkiem rodziny jest przekazanie wiary. Dokonuje się to przez przekazanie prawd wiary, praktykę modlitwy i życia sakramentalnego, a zwłaszcza przez osobisty przykład rodziców (kan. 835 § 4$)^{6}$.

$2 \mathrm{KPK} / 83$, kan. 226 § 2: „Rodzice, ponieważ dali dzieciom życie, mają bardzo poważny obowiązek i prawo ich wychowania. Stąd też na pierwszym miejscu do chrześcijańskich rodziców należy troska o chrześcijańskie wychowanie dzieci, zgodnie z nauką przekazywaną przez Kościół”.

$3 \mathrm{KPK} / 83$, kan. 793 § 1: „Rodzice oraz ci, którzy ich zastępują, mają obowiązek i zarazem prawo wychowania potomstwa. Rodzice katoliccy mają ponadto obowiązek i prawo dobrania takich środków i instytucji, przy pomocy których, uwzględniając miejscowe warunki, mogliby lepiej zadbać o katolickie wychowanie swoich dzieci”.

4 KPK/83, kan. 1136: „Rodzice mają najcięższy obowiązek i najpierwsze prawo troszczenia się zgodnie, według swoich możliwości, o wychowanie potomstwa zarówno fizyczne, społeczne i kulturalne, jak i moralne oraz religijne”. Zob. także kan. 1113 KPK/1917: „Parentes gravissima obligatione tenentur prolis educationem tum religiosam et moralem [...]”.

5 Zob. E. Szczot, Ochrona rodziny w prawie Kościoła łacińskiego, Lublin 2011, S. 117 .

$6 \mathrm{KPK} / 83$, kan. 835 § 4: „W zadaniu uświęcania mają swój własny udział również pozostali wierni, uczestnicząc czynnie na swój sposób w nabożeństwach liturgicznych, zwłaszcza w Eucharystii. W szczególny sposób uczestniczą w tej posłu- 
Stąd też dziecko zrodzone z rodziców katolickich ma prawo do chrześcijańskiego wychowania z ich strony (kan. 2177), przy wsparciu przez inne wspólnoty i instytucje (kan. $793 \S 2^{8}, 794 \S 2^{9}, 798^{10}$, $\left.799^{11}, 801^{12}\right)$.

Dlatego w przypadku gdy katolik zawiera małżeństwo z niekatolikiem, winien oświadczyć, że dołoży wszelkich starań, aby

dze rodzice, prowadząc w duchu chrześcijańskim życie małżeńskie i podejmując chrześcijańskie wychowanie dzieci”.

7 KPK/83, kan. 217: „Wierni, którzy to przez chrzest są powoływani do prowadzenia życia zgodnego z doktryną ewangeliczną, posiadają prawo do wychowania chrześcijańskiego, przez które mają być odpowiednio przygotowywani do osiągnięcia dojrzałości osoby ludzkiej i jednocześnie do poznania i przeżywania tajemnicy zbawienia”.

$8 \mathrm{KPK} / 83$, kan. 793 § 2: „Rodzice mają również prawo otrzymania od państwa pomocy potrzebnych do katolickiego wychowania dzieci”.

$9 \mathrm{KPK} / 83$, kan. 794 § 2: „Do duszpasterzy należy obowiązek czynić wszystko, ażeby wszyscy wierni mogli otrzymać katolickie wychowanie”.

$10 \mathrm{KPK} / 83$, kan. 798: „Rodzice powinni kierować swoje dzieci do szkół zapewniających katolickie wychowanie. Jeśli nie mogą tego uczynić, mają obowiązek sami zatroszczyć się o to, by dzieci poza szkołą otrzymały należne wychowanie katolickie".

11 KPK/83, kan. 799: „Wierni mają zabiegać o to, ażeby ustawy państwowe dotyczące kształcenia młodzieży zapewniały jej także w szkole wychowanie religijne i moralne, zgodne z sumieniem rodziców".

$12 \mathrm{KPK} / 83$, kan. 801: „Instytuty zakonne, których właściwym zadaniem jest wychowanie, pozostając wierne swojej misji, niech starają się podejmować katolickie wychowanie również poprzez własne szkoły, zakładane za zgodą biskupa diecezjalnego". 
wszystkie dzieci były ochrzczone i wychowane w Kościele katolickim (kan. 1125, nr 1) ${ }^{13}$.

Według przepisów kodeksów prawa kanonicznego z 1917 i 1983 roku obowiązek wychowania religijnego rozpoczynał się zobowiązaniem do ochrzczenia dziecka jak najszybciej po urodzeniu (KPK/17 kan. 770 $\left.{ }^{14} ; \mathrm{KPK} / 83 \mathrm{kan} .867^{15}\right)$, kontynuowany był przez przygotowanie dziecka do przyjęcia I Komunii Świętej, poprzedzonej spowiedzią, i do przyjęcia sakramentu bierzmowania (KPK/17 kan. $854 \S 4^{16}$,

13 KPK/83, kan. 1125: „Tego rodzaju zezwolenia może udzielić ordynariusz miejsca, jeśli istnieje słuszna i rozumna przyczyna, nie może go jednak udzielić bez spełnienia następujących warunków: $1^{\circ}$ strona katolicka winna [...] złożyć szczere przyrzeczenie, że uczyni wszystko, co w jej mocy, aby wszystkie dzieci zostały ochrzczone i wychowane w Kościele katolickim”. Zob. także: L. Adamowicz, „Bonum prolis” w małżeństwach mieszanych, [w:] W orbicie zasady „odpowiedzialnego rodzicielstwa”. Adekwatne rozumienie pojęcia bonum prolis wyzwaniem dla wspótczesnej kanonistyki, red. A. Pastwa, Katowice 2014 , s. 65-8o.

$14 \mathrm{KPK} / 1917$, kan. 770: „Infantes quamprimum baptizentur; et parochi ac concionatores frequenter fideles de hac gravi eorum obligatione commoneant”.

$15 \mathrm{KPK} / 83$, kan. $867 \S 1$ : „Rodzice mają obowiązek troszczyć się, ażeby ich dzieci zostały ochrzczone w pierwszych tygodniach [...]” § 2: „Jeśli dziecko znajduje się w niebezpieczeństwie śmierci, powinno być natychmiast ochrzczone”. Zob. także S. Congregatio Doctrina Fidei, Instructio de Baptismo parvulorum Pastoralis actio, AAS 72 (1980), s. 1132-1156, 28 [dalej: PA]. Polskie tłum.: Kongregacja Nauki Wiary, Instrukcja o chrzcie dzieci Pastoralis actio, [w:] W trosce o petnię wiary, red. J. Królikowski, Z. Zimowski, Tarnów 1997.

$16 \mathrm{KPK} / 1917$, kan. 854 § : „De sufficienti puerorum dispositione ad primam communionem iudicium esto sacerdoti a confessionibus eorumque parentibus aut iis qui loco parentum sunt". 
kan. 860

Prawo dziecka do chrztu uzasadnia instrukcja Kongregacji Nauki Wiary Pastoralis actio ${ }^{20} \mathrm{z} 1980$ roku w nr. 15:

Tak na Wschodzie, jak na Zachodzie praktykę udzielania Chrztu dzieciom uważa się za normę niepamiętnej tradycji. Orygenes, a po nim św. Augustyn uważali tę praktykę za „tradycję przejętą od Apostołów". Chociaż pierwsze wyraźne świadectwa pochodzą z drugiego wieku, to jednak żadne z nich nie przedstawia Chrztu dzieci jako czegoś nowego. Św. Ireneusz, obok innych, uważa za oczywiste i zgodne z tradycją wyliczanie wśród ochrzczonych „niemowląt i dzieci”, razem z dorastającymi, młodzieńcami i starcami. Najstarszy z Obrzędów, pochodzący z początku III wieku, nazywany Tradycja Apostolską, zawiera taki przepis: „Chrzcijcie najpierw dzieci: wszystkie, które mogą mówić we własnym imieniu, niech same to czynią; jeśli natomiast chodzi o te, które nie mogą jeszcze mówić we własnym imieniu, niech mówią za nich rodzice albo ktoś z ich rodziny”. Natomiast św. Cyprian, uczestnicząc w Synodzie Biskupów Afrykańskich,

17 KPK/1917, kan. 860: „Obligatio praecepti communionis sumendae, quae impuberes gravat, in eos quoque ac praecipue recidit, qui ipsorum curam habere debent, idest in parentes, tutores, confessarium, institutores et parochum”.

$18 \mathrm{KPK} / 83$, kan. 890: „Wierni są obowiązani przyjąć ten sakrament w odpowiednim czasie. Rodzice, duszpasterze, zwłaszcza proboszczowie, mają troszczyć się, żeby wierni zostali właściwie przygotowani do jego przyjęcia i w odpowiednim czasie do niego przystąpili”.

19 KPK/83, kan. 914: „Jest przede wszystkim obowiązkiem rodziców oraz tych, którzy ich zastępują, jak również proboszcza, troszczyć się, ażeby dzieci, po dojściu do używania rozumu, zostały odpowiednio przygotowane i jak najszybciej posiliły się tym Bożym pokarmem, po uprzedniej sakramentalnej spowiedzi”.

20 AAS 72 (1980), s. 1137-1156; tłumaczenie polskie: www.opoka.org.pl/biblioteka/W/WR/kongregacje/kdwiary/zbior/t_1_42.html (12.01.2015). 
oświadcza, że „żadnemu narodzonemu człowiekowi nie należy odmawiać miłosierdzia Bożego i łaski". Dlatego też wspomniany Synod, stwierdzając, że „wszyscy ludzie są równi”, niezależnie od wielkości i wieku, uznał za zgodne z prawem „udzielanie Chrztu w drugim lub trzecim dniu po narodzeniu"21.

Odnosząc się do krytyki powyższej praktyki, Kongregacja stwierdza:

Biorąc pod uwagę sam naturalny porządek rzeczy, dostrzegamy, że rodzice troszczą się o to, co jest konieczne dla życia i ma na względzie dobro dzieci. Sposób zachowania się rodziny w odniesieniu do życia religijnego dziecka, określany jako neutralny, byłby w rzeczywistości życzeniem zła, ponieważ pozbawiałby je istotnego dobra. Zwłaszcza ci, którzy utrzymują, że przez Chrzest stosuje się przemoc wobec wolności dziecka, nie dostrzegają tego, że wszyscy ludzie - również nieochrzczeni - jako stworzenia - są związani obowiązkami względem Boga, których nie mogą pominąć, a które Chrzest potwierdza i uszlachetnia przez przybrane synostwo. Nie dostrzegają również tego, że w świetle Nowego Testamentu wejście w życie chrześcijańskie nie stanowi jakiejś formy służby albo ograniczenia człowieka, lecz jest osiągnięciem prawdziwej wolności. Może oczywiście zdarzyć się, że dziecko po osiągnięciu dojrzałości nie zaakceptuje obowiązków wypływających z Chrztu. W takim jednak przypadku rodzice dziecka, chociaż ten fakt będzie sprawiał im ból, na pewno nie będą wyrzucać sobie, że działając zgodnie z przysługującym im prawem i obowiązkiem, zatroszczyli sięo Chrzest dziecka i wychowanie chrześcijańskie. Wbrew przewidywaniom, pewnego dnia mogą odżyć złożone w duszy dziecka zaczątki wiary, a rodzice będą przyczyniać się do tego przez ich cierpliwość i miłość, modlitwę i autentyczne świadectwo wiary ${ }^{22}$.

21 PA 4.

22 PA 22. 
Z kolei w przepisach dawnego prawa karnego prawodawca zastrzegł, że karę ekskomuniki latae sententiae zaciągali ci katolicy, którzy zawierając małżeństwo, bezpośrednio lub pośrednio uzgodnili, że wszystkie lub niektóre dzieci wychowają poza Kościołem katolickim (kan. 2319, n. 4) ${ }^{23}$. W kodeksie z 1983 roku prawodawca przewidział natomiast sankcje karne dla rodziców i ich zastępców, którzy oddają dzieci do chrztu lub na wychowanie w religii niekatolickiej (kan. 1366) ${ }^{24}$.

Można stwierdzić, że podjęcie przez rodziców obowiązku wychowania religijnego dziecka skutkuje nabyciem przez dziecko przynależności do wspólnoty Kościoła.

\section{Pojęcie dziecka}

W sensie ścisłym dzieckiem jest osoba fizyczna, która nie ukończyła siódmego roku życia. Prawodawca w kan. 97 § $2^{25}$ stanowi, że małoletni przed ukończeniem siódmego roku życia nazywa się dzieckiem (infans) i uważany jest za osobę, która nie posiada „używania rozumu” (non sui compos). Dziecko nie posiada zdolności do czynności prawnych oraz nie podlega ustawom czysto

$23 \mathrm{KPK} / 1917$, kan. 2319 §1: Subsunt excommunicationi latae sententiae Ordinario reservatae catholici: [...] $4^{\circ}$ Parentes vel parentum locum tenentes qui liberos in religione acatholica educandos vel instituendos scienter tradunt. $§ 2$. Ii de quibus in $\S 1$, nn. 2-4, sunt praeterea suspecti de haeresi”.

$24 \mathrm{KPK} / 83$, kan. 1366 „Rodzice lub ich zastępujący, którzy oddają dzieci do chrztu lub na wychowanie w religii niekatolickiej, powinni być ukarani cenzurą lub inną sprawiedliwą karą".

25 KPK/83, kan. 97 § 2: „Małoletni, przed ukończeniem siódmego roku życia, nazywa się dzieckiem i uważany jest za nie posiadającego używania rozumu. Po skończonym siódmym roku życia domniemywa się, że posiada używanie rozumu”. 
kościelnym ${ }^{26}$. Z dzieckiem zrównany jest, gdy chodzi o chrzest, także ten, kto nie jest świadomy swojego działania (kan. 99²7, kan. $\left.852 \S 2^{28}\right)$. Z tej racji w czynnościach prawnych dziecko zastępują rodzice lub prawni opiekunowie (kan. $98 \S 2^{29}$ ). Dziecko nie jest też zdolne do popełnienia przestępstwa (kan. 1323, $1^{\circ}, 6^{\circ}$ ).

Należy jednak zauważyć, że prawodawca daje pełne uprawnienia w zakresie nabycia przynależności do Kościoła dopiero osobom, które ukończyły 14 rok życia ${ }^{30}$. Prawodawca odnosi się także (w kan. 110)

$26 \mathrm{KPK} / 83$, kan. 11: „Ustawom czysto kościelnym podlegają ochrzczeni w Kościele katolickim lub do niego przyjęci, którzy jednak posiadają wystarczające używanie rozumu oraz - jeśli ustawa czego innego wyraźnie nie zastrzega - ukończyły siódmy rok życia”.

27 KPK/83, kan. 99: „Ktokolwiek na stałe nie posiada używania rozumu, uznany jest za nieodpowiedzialnego i przyrównany dzieciom”.

$28 \mathrm{KPK} / 83$, kan. 852 § 2: „Z dzieckiem zrównany jest, gdy chodzi o chrzest, także ten, kto nie jest świadomy swego działania”.

$29 \mathrm{KPK} / 83$, kan. 98 § : „W wykonywaniu swoich uprawnień osoba małoletnia podlega władzy rodziców lub opiekunów, z wyjątkiem tych spraw, w których małoletni na podstawie prawa Bożego lub kanonicznego są wyjęci spod ich władzy; co do ustanowienia opiekunów oraz ich władzy, należy zachować przepisy prawa cywilnego, chyba że w prawie kanonicznym co innego zastrzeżono albo biskup diecezjalny uznał w pewnych wypadkach, ze słusznej przyczyny, że należy zaradzić temu przez ustanowienie innego opiekuna”.

30 KPK/83 kan. $111 \S 2$ : „Każdy z mających być ochrzczonym, który ukończył czternasty rok życia, może dobrowolnie wybrać chrzest w Kościele łacińskim lub Kościele innego samodzielnego obrządku; w takim wypadku należy do tego Kościoła, który wybrał”. KKKW kan. 3o. „Każdy mający przyjąć chrzest, który ukończył czternasty rok życia, może w sposób wolny wybrać każdy Kościół sui iuris, do którego nabywa przynależność przez przyjęcie w nim chrztu, z zachowaniem prawa partykularnego zatwierdzonego przez Stolicę Apostolską”. KKKW kan. 900 
do statusu dzieci przysposobionych (adoptowanych), zrównując je w ich statusie z dziećmi naturalnymi ${ }^{13}$. Powyższe ustalenia określają, kim jest podmiot dalszego ciągu niniejszego opracowania.

\section{Chrzest podstawą przynależności do Kościoła katolickiego}

Z natury rzeczy nie można zostać członkiem Kościoła Jezusa Chrystusa bez przyjęcia chrztu. Sama celebracja chrztu, polegająca na polaniu wodą lub zanurzeniu w wodzie przy równoczesnym wypowiedzeniu formuły trynitarnej nie może być uważana za jedyne, aczkolwiek konieczne, kryterium włączenia do jednego z wyznań chrześcijańskich. Można stwierdzić, że przyjęcie chrztu w konkretnej wspólnocie wyznaniowej daje co najwyżej podstawę do domniemania włączenia neofity do tejże wspólnoty. Uzasadnieniem dla tej tezy może być możliwość ważnego i legalnego udzielenia chrztu przez osobę, która sama jest nieochrzczona, a więc bezwyznaniowa ${ }^{32}$. Jakie więc inne kryteria należy wziąć pod uwagę, aby ustalić faktyczne nabycie przynależności?

Wydaje się, że należałoby wziąć pod uwagę następujące przesłanki: naturalne prawo każdego człowieka do wolności religijnej, respektowanie naturalnego prawa rodziców do wychowania dzieci i wynikające z nich wolność decyzji i intencja zarówno kandydata do chrztu (w przypadku gdy chrzest przyjmuje w wieku rozeznania), jak i wolność decyzji i intencja rodziców lub prawnych opiekunów (istotna zwłaszcza przy chrzcie dzieci).

§ 1: „Ten, kto nie ukończył 14 roku życia, nie może zostać przyjęty [do Kościoła katolickiego], jeśli opierają się temu jego rodzice”.

$31 \mathrm{KPK} / 83$, kan. 110: „Dzieci adoptowane zgodnie z przepisami prawa cywilnego uważane są za dzieci tego lub tych, którzy je adoptowali”.

32 Zob. KKK, 1256; KPK/83 kan. 861 § 2. 
Istotnym wydaje się w tym zakresie nauczanie Vaticanum II zawarte w deklaracji o wolności religijnej Dignitatis humanae33. Ojcowie soborowi stwierdzili, że „każdej rodzinie, jako społeczności cieszącej się własnym i pierwotnym prawem, przysługuje uprawnienie do swobodnego organizowania życia religijnego w ognisku domowym pod kierunkiem rodziców. Rodzicom zaś przysługuje prawo do tego, aby według własnych swych poglądów religijnych rozstrzygali, jaki rodzaj nauczania religijnego ma być udzielany ich dzieciom" 34 .

Fundamentalną w tym zakresie zasadę podaje także najwyższy prawodawca w kan. 748 § 2 KPK/83, stwierdzając, że „ludzie nie mogą być przez nikogo zmuszani do przyjęcia wiary katolickiej wbrew własnemu sumieniu" ${ }^{35}$ oraz w kan. 774 § 2, gdy deklaruje, że „rodzice przed innymi mają obowiązek słowem i przykładem formować dzieci w wierze i praktyce życia chrześcijańskiego. Podobny obowiązek spoczywa na tych, którzy zastępują rodziców, oraz na chrzestnych" ${ }^{6}$. Stąd też nikt nie ma prawa do zmuszania do przyjęcia chrztu w ogólności ani do przyjęcia chrztu w określonej wspólnocie wyznaniowej.

Również „żadnego nieochrzczonego człowieka, kiedy ten pragnie przyjąć chrzest, nie wolno na podstawie jakichś czynników, na które nie może mieć on wpływu, włączyć do Kościoła katolickiego”37.

33 Sacrosanctum Concilium Oecumenicum Vaticanum II, Declaratio de libertate religiosa Dignitatis humanae, 7.12.1965, AAS 58 (1966), s. 929-946.

34 Sacrosanctum Concilium Oecumenicum Vaticanum II, Declaratio de libertate religiosa Dignitatis humanae, 5 .

35 Tak samo kan. 586 KKKW.

36 Tak samo kan. 618 KKKW.

37 M. Zaborowski, Nabycie przynależności do Kościoła katolickiego, Lublin 2013, S. 200. 
Zdaniem Marka Zaborowskiego „ponieważ prawo do wolności religijnej ugruntowane jest i osadzone w godności ludzkiej jednostki i przez to w prawie naturalnym, należy respektować wolność człowieka w wyborze jego wiary i jego przynależności religijnej, także w przypadku chrztu dziecka przed ukończeniem siódmego roku życia czy też w przypadku tych, którzy nie osiągnęli sprawności umysłowej lub w trwały sposób ją utracili, a ponieważ takie osoby nie mogą same korzystać ze swych podstawowych praw czy też ich dochodzić, także przy wyborze wspólnoty religijnej potrzebują one zastępstwa rodziców czy opiekunów prawnych"38.

Ważną zasadę formułuje ponadto Papieska Rada do Spraw Popierania Jedności Chrześcijan w Dyrektorium z 1993 roku. Stwierdza, że „chociaż przez chrzest osoba zostaje wcielona w Chrystusa i w Kościół, dokonuje się to konkretnie w Kościele lub w określonej Wspólnocie eklezjalnej”39. Nie można więc przyjąć chrztu bez jednoczesnego nabycia przynależności do konkretnej wspólnoty wyznaniowej.

Stąd też nie mają znaczenia decydującego ani miejsce chrztu, ani osoba szafarza, ale pochodzenie naturalne dziecka w połączeniu z intencją jego rodziców lub prawnych opiekunów. Przez analogię te same argumenty dotyczą nabycia przynależności dziecka do Kościoła sui iuris.

\subsection{Miejsce udzielenia chrztu}

Co do zasady chrzest dziecka zrodzonego z rodziców katolickich lub z małżeństwa mieszanego winien odbyć się kościele parafialnym, właściwym ze względu na zamieszkanie lub ze względu na

38 M. Zaborowski, Nabycie przynależności do Kościoła katolickiego, dz. cyt., S. $200-201$. 
przynależność do parafii personalnej według jej statutów ${ }^{40}$. Dopuszczalne jest również ochrzczenie w innym miejscu świętym, a nawet $\mathrm{w}$ innym odpowiednim miejscu ${ }^{41}$, ale co do zasady nie w domu prywatnym i szpitalu, chyba że w wypadku konieczności lub za zgodą ordynariusza miejsca ${ }^{42}$. Nieco inaczej kwestię tę reguluje Kodeks kanonów Kościołów wschodnich, dając możliwość, o ile przewiduje to prawo partykularne, chrztu w domach prywatnych ${ }^{43}$. Jednak miejsce celebracji nie pociąga za sobą nabycia przynależności wyznaniowej, gdyż ustawodawca ponadto przewi-

4o KPK/83, kan. 857: „§ 1. Poza wypadkiem konieczności, właściwym miejscem chrztu jest kościół lub kaplica. § 2. Należy uważać za regułę, że dorosły ma przyjmować chrzest we własnym kościele parafialnym, dziecko zaś w kościele parafialnym jego rodziców, chyba że co innego doradza słuszna przyczyna”.

$41 \mathrm{KPK} / 83$, kan. 858 § 2: „Ordynariusz miejsca, wysłuchawszy zdania proboszcza, może dla wygody wiernych zezwolić lub nakazać, ażeby chrzcielnica była także w innym kościele lub kaplicy na terenie parafii”. Kan. 859: „Jeśli kandydat do chrztu, ze względu na odległość lub inne okoliczności, nie może bez poważnej niedogodności przybyć lub być przyniesiony do kościoła parafialnego albo innego kościoła lub kaplicy, o których w kan. 858, § 2, chrztu można i trzeba udzielić w innym bliżej położonym kościele lub kaplicy albo nawet $\mathrm{w}$ innym odpowiednim miejscu".

42 KPK/83, kan. 860: „§ 1. Poza wypadkiem konieczności, chrztu nie należy udzielać w domach prywatnych, chyba że ordynariusz miejsca zezwoli na to dla poważnej przyczyny. § 2. Jeśli biskup diecezjalny nie zarządzi inaczej, chrztu nie należy udzielać w szpitalach, chyba że zmusza do tego konieczność lub inna racja duszpasterska”.

43 KKKW, kan. 687: „§ 1. Poza wypadkiem konieczności, chrztu należy udzielać w kościele parafialnym, z zachowaniem prawnych zwyczajów. § 2. W domach prywatnych chrzest może być udzielany według norm prawa partykularnego lub za pozwoleniem Hierarchy miejsca”. 
duje możliwość udostępnienia budynku kościoła chrześcijanom niekatolikom, którzy nie posiadają własnego godnego miejsca do sprawowania kultu44. Stąd kościół lub dom modlitwy określonego wyznania miejsce celebracji chrztu może rodzić domniemanie nabycia przynależności do wspólnoty wyznaniowej, która jest jego właścicielem lub użytkownikiem, ale nie przesądza o tym fakcie w sposób bezwzględny. To samo dotyczy udzielenia chrztu w kościele innego obrządku. Inne aspekty tego zagadnienia wiążą się z osobą szafarza, o czym poniżej.

\subsection{Osoba szafarza chrztu}

Zasady doktrynalne i przepisy prawa ściśle określają wymogi, jakie winna spełniać osoba udzielająca chrztu, czyli jego szafarz. Szafarzem chrztu może być tylko jedna osoba. Jest nią więc w Kościele katolickim biskup, prezbiter lub diakon. Może nią być także, zgodnie z katolickimi zasadami, każda inna osoba, nawet nieochrzczona, która ma intencję uczynienia tego, co czyni Kościół, gdy chrzci, i używając wody, wypowie formułę trynitarną45.

Dyrektorium ekumeniczne jako zasadę podaje ponadto, że „chrztu nie powinni udzielać razem dwaj szafarze należący do

44 Zob. KKKW, kan. 670 § 2: „Jeżeli chrześcijanie akatolicy nie mają miejsca, w którym mogliby godnie sprawować kult Boży, biskup eparchialny może zezwolić na używanie budynku katolickiego, cmentarza lub kościoła, według prawa partykularnego własnego Kościoła sui iuris".

45 KKK 1256: „Zwyczajnym szafarzem chrztu jest biskup i prezbiter, a w Kościele łacińskim także diakon. W razie konieczności może ochrzcić każda osoba, nawet nieochrzczona, mająca wymaganą intencję, używając trynitarnej formuły chrzcielnej. Wymagana intencja polega na tym, aby chcieć uczynić to, co czyni Kościół, gdy chrzci. Kościół widzi uzasadnienie tej możliwości w powszechnej woli zbawczej Boga oraz konieczności chrztu do zbawienia”. 
różnych Kościołów lub Wspólnot eklezjalnych. Zresztą zgodnie z katolicką tradycją liturgiczno-teologiczną chrzest jest udzielany przez jednego tylko celebransa. Ze względów duszpasterskich ordynariusz miejsca może jednak, w wyjątkowych okolicznościach, dozwolić, by szafarz jakiegoś Kościoła lub Wspólnoty eklezjalnej uczestniczył w celebracji, wykonując czytanie lub odmawiając modlitwę itd. Taka wzajemność jest możliwa tylko pod warunkiem, że chrzest sprawowany w innej Wspólnocie nie przeciwstawia się ani zasadom, ani dyscyplinie katolickiej" ${ }^{46}$.

Identyfikacja ochrzczonego z konkretną wspólnotą wyznaniową, zwłaszcza gdy chodzi o osobę szafarza, narzuca się w sposób wyraźny. Wyświęcony szafarz jako urzędowy przedstawiciel swojej wspólnoty włącza do niej neofitę ${ }^{47}$. Podobnie dotyczy to niektórych szafarzy uprawnionych do udzielania chrztu w przypadku konieczności, a więc w Kościele łacińskim będzie to katechista lub inny specjalnie wyznaczony wierny świecki ${ }^{4}$, a w katolickich Kościołach wschodnich duchowny niższych święceń i osoba zakonna.

Należy jednak stwierdzić, że i to domniemanie nabycia przynależności do konkretnej wspólnoty wyznaniowej związane z osobą szafarza nie stanowi kryterium ostatecznego ustalenia tejże przynależności. Ustawodawca w Kodeksie kanonów Kościołów wschodnich przewiduje możliwość udzielenia chrztu dziecku przez szafarza katolickiego na prośbę rodziców niebędących katolikami. Według przepisu kan. $681 \S 5$ KKKW szafarz katolicki

46 Dyrektorium, 97.

$47 \mathrm{KPK} / 83$, kan. 861 § 1: „Zwyczajnym szafarzem chrztu jest biskup, prezbiter i diakon, z zachowaniem przepisu kan. 530, n. 1”.

48 KPK/83, kan. $861 \S 2$ : „Gdy szafarz zwyczajny jest nieobecny lub ma przeszkodę, chrztu godziwie udziela katechista albo inna osoba wyznaczona do tej funkcji przez ordynariusza miejsca”. 
legalnie udziela chrztu, jeśli rodzice tego dziecka - niekatolicy, albo przynajmniej jedno z nich lub osoba prawnie je reprezentująca proszą o to i jest dla nich fizycznie lub moralnie niemożliwe, aby poprosić szafarza swojej wspólnoty ${ }^{49}$. Nie ma wątpliwości, że chrzest udzielony w takiej sytuacji, a w szczególności osoba szafarza nie decydują o nabyciu przynależności do Kościoła katolickiego, gdyż szafarz katolicki działa tu jedynie na prośbę, niejako „zlecenie” rodziców, którzy zachowują nienaruszalne prawo do wychowania swojego dziecka w swojej wierze. Przepis ten jest doniosły także w kontekście dialogu ekumenicznego i chroni przed oskarżeniami o prozelityzm.

W odniesieniu do przynależności obrządkowej również dziecko przyjmujące chrzest przed ukończeniem czternastego roku życia nabywa przynależność do Kościoła sui iuris, niezależnie od przynależności osoby szafarza.

\subsection{Znaczenie przynależności wyznaniowej (obrządkowej) rodziców $i$ ich intencji}

W przypadku chrztu dzieci przed ukończeniem czternastego roku życia rzeczą decydującą o dopuszczeniu do chrztu jest prośba rodziców (prawnych opiekunów) lub przynajmniej jednego z nich, i to, czy dają oni uzasadnioną nadzieję, że dziecko będzie wychowane w wierze katolickiej, a więc czy rodzice faktycznie wprowadzą swoje dziecko do wspólnoty Kościoła. Prośba o chrzest wyrażona przez rodziców zawiera w sobie ich wolę włączenia dziecka nie tylko do wspólnoty Kościoła Jezusa Chrystusa, ale do konkretnie

49 KKKW, kan. 681 § 5: „Dziecko chrześcijan akatolików godziwie jest chrzczone, jeśli rodzice lub przynajmniej jedno z nich, albo ten, który ich prawnie zastępuje, o to proszą i jeśli istnieje fizyczna lub moralna niemożność udania się do własnego szafarza”. 
ukształtowanej w sposób widzialny społeczności wyznaniowej i obrządkowej. Decydującym jest tu zwrócenie się do szafarza określonej wspólnoty wyznaniowej z prośbą o chrzest dla dziecka. Gdyby rodzice mieli inną intencję, musiałaby ona być wyraźnie określona np. poprzez wyjaśnienie, dlaczego rodzice prawosławni proszą o chrzest szafarza katolickiego ${ }^{50}$.

Problem może powstać w małżeństwie mieszanym wyznaniowo przy braku zgodnej decyzji obojga rodziców. Małżonek katolicki złożył zobowiązanie odnośnie do chrztu i wychowania katolickiego wszystkich dzieci zrodzonych z tego związku. Małżonek niekatolicki może bądź powstrzymać się od decyzji w tej kwestii - może milczeć i tym samym pozostawić decyzję drugiej stronie, ale może także sprzeciwić się włączeniu do Kościoła katolickiego swojego dziecka. W takiej sytuacji, poza niebezpieczeństwem śmierci zagrażającym dziecku, wydaje się, że chrzest należy odłożyć do czasu podjęcia wspólnej decyzji przez rodziców dziecka5. Możliwość ochrzczenia dziecka wbrew woli rodziców, nawet w sytuacji niebezpieczeństwa śmierci, przewidziana w kan. 868 § 2 KPK/83 stanowiła zresztą przedmiot krytyki ze strony doktryny ${ }^{52}$. Analogicznie

50 Por. F. M. Capello, Tractatus canonico-moralis. De Sacramentis, vol. 5: De Matrimonio, s. 401: „In dubio, praesumitur adultum, in petendo baptismo, intentionem habuisse se aggregandi religioni, quam minister profitetur, ideoque religioni catholicae, si a ministro catholico baptismi collatio postuletur. [...] Si ignoretur utrum minister sit catholicus necne, v.g. si baptismus conferatur a laico, attendendus est ritus quo sacramentum confertur".

51 Takie postępowanie przewidują przepisy partykularne niektórych diecezji niemieckich, np. Aachen, Essen, Münster, Trewir. Zob. M. Zaborowski, Nabycie przynależności do Kościoła katolickiego, dz. cyt., s. 221-222.

52 Na temat chrztu wobec sprzeciwu rodziców zob. B. Zubert, Chrzest dziecka wbrew woli rodziców, „Prawo Kanoniczne” 39 (1996) nr 3-4, s. 43-64. 
te same zasady należy stosować, gdy chodzi o dziecko przysposobione, dziecko nieznanych rodziców (porzucone) albo osierocone, które nie ma ustanowionego prawnego opiekuna. Można przyjąć, że przynależność kościelna takiego dziecka zależy od statusu wyznaniowego i intencji osoby proszącej o chrzest i zobowiązującej się do katolickiego wychowania.

Potwierdzeniem tego rozstrzygnięcia wydaje się, mutatis mutandis, zasada, którą ustawodawca sformułował w celu określenia przynależności katolika do Kościoła sui iuris, zwana wcześniej przynależnością do obrządku53.

Fundamentalne znaczenie mają kan. 111 KPK/83 i 29 KKKW, które w odniesieniu do dzieci, które nie ukończyły czternastego roku życia, ustalają, że przynależność ich do Kościoła sui iuris zależy od przynależności obrządkowej rodziców: „dziecko, [...] przez chrzest nabywa przynależność do Kościoła sui iuris, do którego należy jego ojciec katolik; jeśli zaś tylko matka jest katoliczką lub jeśli oboje rodzice zgodnie dobrowolnie o to proszą, dziecko nabywa przynależność do tego Kościoła sui iuris, do którego należy jego matka”54. Ponadto zgodnie z kan. 29 § 2 KKKW „dziecko, które nie ukończyło czternastu lat życia, jeśli jest dzieckiem matki niezamężnej, nabywa przynależność do Kościoła sui iuris, do którego należy matka (n. 1); jeśli jest dzieckiem nieznanych rodziców, nabywa przynależność do Kościoła sui iuris, do którego należą ci, którzy prawnie nad nim sprawują opiekę; jeśli są nimi rodzice adoptujący, stosuje się § 1 (n. 2); jeśli jest dzieckiem rodziców nieochrzczonych, nabywa przynależność do Kościoła sui iuris, do którego należą ci,

53 Zob. L. Adamowicz, Przynależność do Kościoła sui iuris, [w:] Przynależność do Kościoła a uczestnictwo wiernych w życiu publicznym, red. J. Krukowski, M. Sitarz, B. Pieron, Lublin 2014, s. 131-150.

54 KKKW, kan. 29 § 1. 
którzy przyjęli na siebie obowiązek wychowania go w wierze katolickiej (n. 3)”. Wobec braku analogicznych przepisów w Kodeksie prawa kanonicznego z 1983 roku powyższy przepis, jako z natury rzeczy regulujący relacje międzyobrządkowe, wiąże także w takich sytuacjach, gdy jedną ze stron małżeństwa jest osoba należąca do Kościoła łacińskiego.

Z wyżej cytowanych przepisów można wnioskować, że istotne znaczenie dla przynależności wyznaniowej i obrządkowej dziecka ma wola rodziców, ograniczona jednak ich własną przynależnością do wspólnoty religijnej.

\section{Zmiana przynależności obrządkowej dzieci55}

Zgodnie z kan. 112 § 1, n. 3 KPK/8 $3^{56}$ oraz 34 KKKW57 dzieci przed ukończeniem czternastego roku życia nie mogą samodzielnie

55 Zob. L. Lorusso, Gli orientali cattolici e i pastori latini. Problematiche e norme canoniche, Roma 2003, s. 69-70.

$56 \mathrm{KPK} / 83$, kan. $112 \S$ 1: „Po przyjęciu chrztu, do Kościoła innego samodzielnego obrządku zostają włączeni: $1^{\circ}$ ci, którzy otrzymali zezwolenie Stolicy Apostolskiej; $2^{\circ}$ małżonek, który zawierając małżeństwo lub w czasie jego trwania oświadczy, że pragnie przejść do Kościoła innego samodzielnego obrządku swego małżonka; po rozwiązaniu jednak małżeństwa może w sposób nieskrępowany powrócić do Kościoła łacińskiego; $3^{\circ}$ dzieci tych, o których mowa w nn. 1 i 2, przed ukończeniem czternastego roku życia, a w małżeństwie mieszanym dzieci strony katolickiej, która zgodnie z przepisami prawa przeszła do Kościoła innego obrządku; po osiągnięciu wskazanego wieku mogą powrócić do Kościoła łacińskiego”.

57 KKKW, kan. 34: „Jeśli do innego Kościoła sui iuris przechodzą rodzice lub w małżeństwie mieszanym małżonek katolicki, dzieci poniżej czternastego roku życia z mocy samego prawa nabywają przynależność do tego samego Kościoła sui iuris; jeśli zaś w małżeństwie między katolikami jedno tylko z rodziców przechodzi do innego Kościoła sui iuris, dzieci przechodzą jedynie w tym wypadku, jeśli wy- 
podejmować decyzji w przedmiocie zmiany przynależności do Kościoła sui iuris. Stąd też takie dzieci małżonków katolickich, którzy zmienili przynależność do Kościoła sui iuris, automatycznie zmieniają tę przynależność. Dotyczy to sytuacji, w której oboje katoliccy rodzice zgodnie złożyli taką deklarację lub w małżeństwie mieszanym uczynił to małżonek katolicki. Dziecko nie zmienia przynależności, gdy przynależność zmienia tylko jedno z rodziców przy sprzeciwie drugiego małżonka katolickiego. Ponadto prawodawca stanowi, że dzieci te po osiągnięciu 14 roku życia mogą powrócić do Kościoła chrztu. Te same zasady obowiązują w przypadku przysposobienia lub zmiany instytucji opiekuńczej lub prawnego opiekuna.

Natomiast odnośnie do zmiany przynależności wyznaniowej, a konkretnie przyjęcia dziecka już ochrzczonego poza Kościołem katolickim do pełnej wspólnoty, prawodawca w KKKW w kan. 900 § 1 stwierdza, że „ten, kto nie ukończył 14 roku życia, nie może zostać przyjęty, jeśli sprzeciwiają się temu jego rodzice”. Stąd wydaje się logiczne, że nie ma przeszkód w przyjęciu do pełnej wspólnoty z Kościołem katolickim tych dzieci, które przechodzą wraz $\mathrm{z}$ rodzicami lub za ich zgodą.

Pozostaje problem „wystąpienia z Kościoła” osób znajdujących się pod władzą rodzicielską. Wydaje się, że - analogicznie do wyżej przedstawionego przepisu o przyjęciu do Kościoła - przed ukończeniem 14 roku życia dziecko nie może skutecznie podjąć takiej decyzji przy sprzeciwie rodziców. Za taką tezą przemawiają także przepisy kościelnego prawa karnego, które przewidują odpowiedzialność karną za przestępstwo apostazji i schizmy katolików,

razili na to zgodę oboje rodzice; po ukończeniu zaś czternastego roku życia dzieci mogą powrócić do poprzedniego Kościoła sui iuris”. 
którzy ukończyli 16 rok życia (katolicy łacińscy) ${ }^{58}$ lub 14 rok życia (katolicy wschodni) ${ }^{59}$. Gdyby natomiast decyzję o opuszczeniu Kościoła katolickiego podjęli rodzice, wydaje się, że w przypadku dzieci do 7 roku życia decyzja ta dotyczyłaby również tych dzieci, natomiast problematyczny pozostaje przypadek dzieci pomiędzy 7 a 14 rokiem życia. W przypadku chrztu takich dzieci, uznając ich zdolność do wyrażenia woli, wymaga się od nich przyłączenia się do prośby rodziców o chrzest ${ }^{60}$. Czy decyzja dziecka w tym wieku o pozostaniu w Kościele katolickim pomimo odstępstwa rodziców byłaby uprawniona i skuteczna? Wydaje się, że w świetle wyżej przywołanych przepisów należy udzielić odpowiedzi twierdzącej.

Zagadnienie przynależności dziecka do Kościoła i obrządku wymaga więc roztropnego interpretowania i stosowania przepisów prawa kanonicznego z uwzględnieniem naturalnego prawa do wolności religijnej oraz respektowania praw rodziców do wychowania swoich dzieci. Pogodzenie tych zasad niejednokrotnie może być trudne, zwłaszcza w rodzinach, w których są osoby o różnej przynależności wyznaniowej lub nieidentyfikujące z żadną wspólnotą. Ponadto wiele problemów wynika także z laickiego stylu życia, w którym w imię źle pojętej tolerancji i wolności identyfikacja ze wspólnotą wyznaniową schodzi na dalszy plan, a wychowanie religijne dzieci jest odkładane na czas, w którym dzieci po osiągnięciu odpowiedniego wieku same zdecydują o swoim życiu religijnym. Stąd też przypominanie i formowanie do odpowiedzialności za przekazanie nie tylko wiary w Boga, ale także identyfikacji ze

58 KPK/83, kan. 1323: „Nie podlega żadnej karze, kto w chwili przekraczania ustawy lub nakazu: $1^{\circ}$ nie ukończył jeszcze szesnastego roku życia”.

59 KKKW, kan. $1413 \S 1$ : „Nie podlega żadnej karze ten, kto nie ukończył czternastego roku życia”.

6o Zob. Ordo initiationis christianae adultorum, Città del Vaticano 1972, rozdz. 5. 
wspólnotą Kościoła oraz wskazywanie zasad, którymi winni się kierować w tym zakresie zarówno rodzice, jak i duszpasterze, jest szczególnie ważnym obowiązkiem.

SUMMARY

\section{The membership of Church and enrollment in a Church sui iuris in case of a child}

In the Catholic Church there are 23 eastern Churches sui iuris. Sometimes, in case of a marriage of the two Catholics who belong to different Catholic Churches, the problem of the membership of Church and enrollment in a Church sui iuris of a child can appear. The paper presents the legal aspects of the problem. Memberships in question are, first of all, the results of the education of a child, but they can be changed according to law- two codes (CIC 1983 and CCEC 1988) contain provisions that regulate the matter. Also the intention of the parents has its legal significance, and, of course, the baptism.

Keywords: rite, Church sui iuris, baptism, education, freedom of religion

ks. Leszek Adamowicz, Przynależność kościelna i obrządkowa dziecka, [w:] Prawa dziecka: perspektywa Kościoła, red. ks. Piotr Kroczek, Kraków 2015, s. 9-29 (Annales Canonici Monographiae, 3).

DOI: http://dx.doi.org/10.15633/9788374384353.02 